\title{
The Qadan, the Jebel Sahaba Cemetery and the Lithic Collection
}

\section{Donatella Usai ${ }^{a}$}

The Late Pleistocene, Early and Middle Holocene Nubian cultural sequence was constructed after the pioneering work done in Nubia in the 1960s (Irwin et al., 1968; Wendorf ed. 1968c; Marks 1970; Nordström ed. 1972). Most of the prehistoric sites located by the expeditions during the Nubian Campaign were surface concentrations and their dating was made on the basis of their location on ancient Nile deposits attested at different levels: the Dibeira-Jer, Ballana, Sahaba, Birbet and Arkin formations (De Heinzelin 1968). Absolute elevation was also considered as relevant to a site's date.

Within this cultural sequence, the Qadan (Shiner 1968a) was usually associated with the Sahaba Formation, whose beginning was more or less established at 16,500 BP (De Heinzelin 1968), and the Jebel Sahaba cemetery (site 117) was attributed to this same cultural phase.

The Qadan sequence has been already discussed by the author (Usai 2008a) in a paper demonstrating that Shiner's hypothesis that the Abkan Neolithic complex originated directly from the Qadan needed revision. This contribution continues this discussion but to suggest that it now appears that the Jebel Sahaba cemetery cannot be possibly associated with the Qadan. In doing so, it notes some possible discrepancies and some important factors.

KEY-WORDS: Sudan, Nubia, Qadan, lithic technology, Jebel Sahaba, cemetery chronology

\section{INTRODUCTION}

A re-analysis of the Late Pleistocene, Early and Middle Holocene cultural sequence of the Nubian region (Fig. I) has recently led to a revaluation of the Qadan and the Abkan lithic industries (Usai 2008a). ${ }^{1}$ In particular the position of the Abkan, considered to be

a Centro Studi Sudanesi e Sub-Sahariani, Strada Canizzano I28/D, Treviso - Italy; e-mail: donatellausaisalvatori@gmail.com; ORCID: 0000-0001-9379-9015

1 In fact the Qadan sequence had already been widely criticized by Wendorf himself (1968a: 938) and using similar arguments. In the volume Prehistory of Nubia, on page 938, he states that "Study of the tool kits may provide, an indication of what activities characterized each group" adding that "This conclusion also suggests that the Early, Middle and Late stages of the Qadan also have little chronological significance". However Wendorf never raised the question of the link between the Qadan and the Abkan, that of the mixing of assemblages belonging to different cultural phases, and of the relationship of the Qadan with the lithic complexes of the initial phases of the Holocene. For some reasons, 
IOO $\mid$ Donatella Usai

directly linked to the Qadan (Shiner 1968a), a Late Palaeolithic complex, and the relationship of the Qadan with the Ballanan, Arkinian, and the succeding Shamarkian, a Mesolithic complex, and Post-Shamarkian, were considered in this review (Usai 2008a).

An important point in this analysis was that rather than using tool indexes to define the characters of a particular complex, it was considered much better to rely on some of the technological aspects. In fact, the production of a range of tools may be connected to specific activities in a certain area (Binford 1979; 1980; but also Wendorf 1968a: 937) therefore it is here considered deceptive to use similiarities and differences in tool production as a means to evaluate relationships between lithic complexes. An analysis that would consider more the technological aspects of the lithic production would probably result in a less misleading picture, these aspects may act in the same way as the "cifre morelliane" in painting (Lermolieff I890).

In this analysis, core treatment (platform orientation, number of platform, types of platforms) with its dimensional aspects were taken into account as the most characteristic elements of the assemblages. Other unequivocal stylistic variables regarding stone tool categories were considered afterwards.

The context of discovery (Table I), was considered of primary importance. This means ascertaining which of the assemblages described for the Qadan and the Abkan really pertained to a single cultural phase and which could be considered a collection resulting from deflation of different non-contemporaneous occupations. Most of the prehistoric sites located by the many expeditions working in the Nubian Campaign were, in fact, surface concentrations, and their dating was made on the basis of their location on ancient Nile deposits attested at different levels partially within, over or under the Ballana and Sahaba formations (Table I; De Heinzelin 1968). ${ }^{2}$

This re-analysis has led to a complete revision of the Qadan sequence. Therefore, as a first consequence, if this sequence can no longer be regarded as reliable, then the phylogenesis of the Abkan Neolithic directly from the Qadan needs to be reconsidered as well as the relationship of the Abkan with other lithic complexes of the region preceding it (Fig. 2). Secondly, it has opened up the possibility of considering a more "linear" development of Nubian Late Prehistoric cultures (Fig. 2). Finally, as the Jebel

his opinion on the Qadan sequence never emerged clearly so that, years after, some authors have come to fantasize, for example, about the oldest pottery production in Sudan in the Qadan period (Welsby 1997) or still consider the Abkan a lithic industry directly linked to the Qadan (D'Ercole 20I7). Maybe this is partially due to the fact that Wendorf in the same volume (1968b: 990), contradicting himself and, again, following Shiner (1968a) states also that "the Qadan industry is estimated to have begun around $\mathrm{I} 3,000 \mathrm{BC}$ and to have continued until the appearance of pottery around $5000 \mathrm{BC}$ ".

2 The sequence of Nilotic events has been completely revisited by Wendorf and Schild (1989) after comparison with the evidence encountered further to the north in Egypt, in the Wadi Kubbaniya area; the Ballana formation is now included in the Late Palaeolithic Alluviation beginning more or less $c .20,000 \mathrm{BP}$ (Wendorf and Schild 1989: 777). 


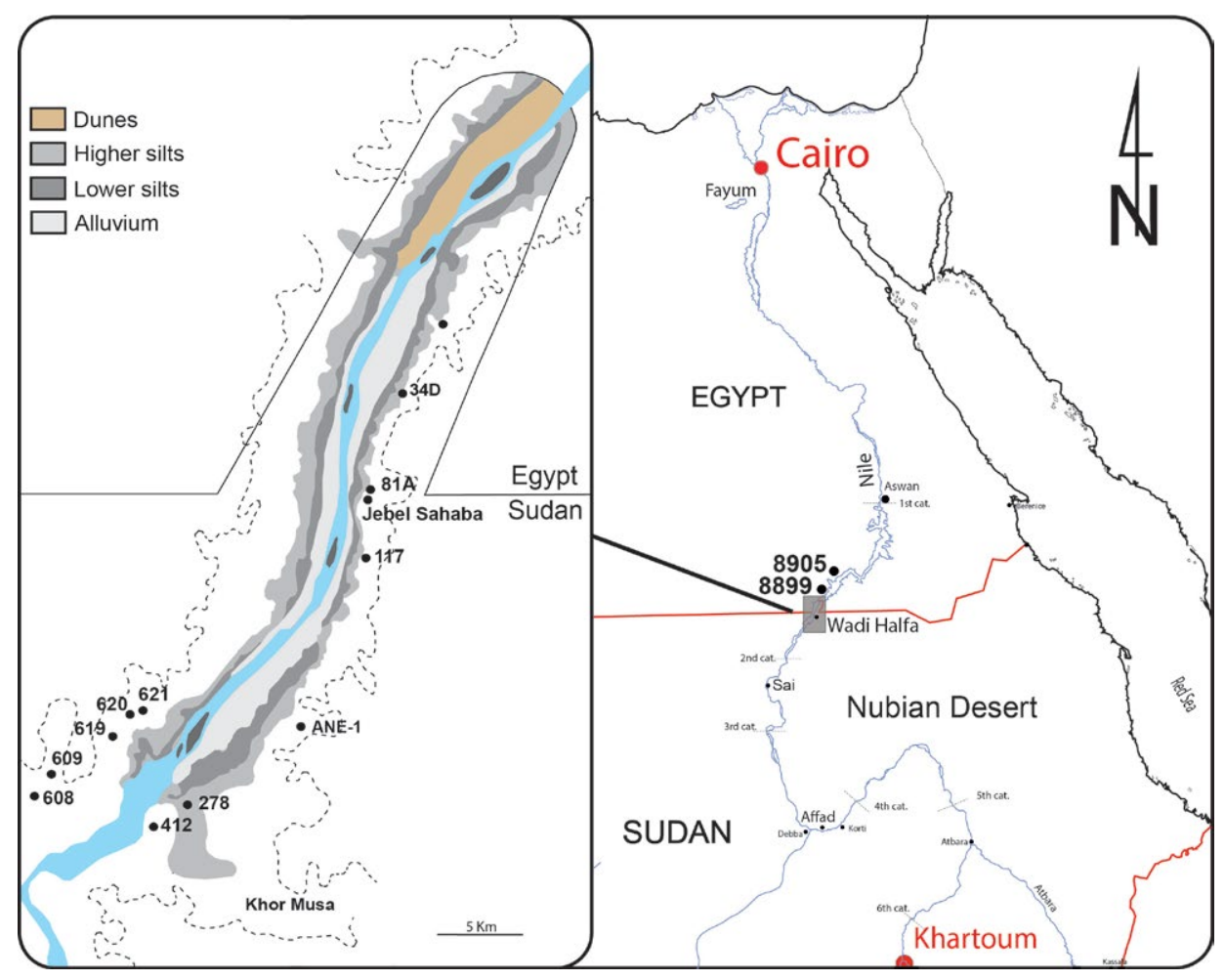

Fig. I. Map with the location of sites mentioned in the text. Drawn: D. Usai.

Sahaba cemetery has been associated with the Qadan, a few observations can be made on the lithic assemblage recovered at the site and, additionally, on its dating. These lead to the conclusion that this association is debatable.

\section{THE QADAN: THE SEQUENCE AND ITS CHARACTERIZATION}

Shiner divided the Qadan into Early, Middle, Late and Final (Shiner 1968a), and considered that the Abkan directly evolved from this lithic industry. Both Wendorf (1968a: 938, 99I) and Marks (1970: 2I) questioned this partition as they considered it inconsistent. ${ }^{3}$ What probably led Shiner to hypothesise a Qadan periodisation was a "myopic" view that hindered him from realising that many Qadan sites are mixed with assemblages of later periods and thus include elements typical of the Abkan or

\footnotetext{
3 See note I.
} 




Fig. 2. The geologicalcultural-chronological scheme of the Nubian sequence before and after revision. Drawn: D. Usai.

the Khartoum Variant. ${ }^{4}$ He instead interpreted these intrusive elements as representing characteristics of a later development within the Qadan itself. The Late and Final Qadan are those that in Shiner's opinion would represent the stages closest to the evolution towards the Abkan.

Except site 608 (Fig. I; Shiner 1968a), found on the eroded surface of the DibeiraJer Formation at an extremely high absolute elevation (I55 m a.s.l.), and sites 8899 and 8905 (Fig. I) that, according to Wendorf (1968a), were resting on the sands of the Ballana Formation and were covered by silts of the Sahaba Formation, most other

4 There are a number of different indications of admixture. A clear one is the presence, in the assemblages formerly assigned to the Qadan, of the Egyptian flint which is very common in Arkinian, Shamarkian (Schild etal., 1968) and Khartoum Variant sites (Shiner 1968b; Usai 2005). Egyptian flint is present at Qadan sites 608, 619, 620, 621, 1023 and 1041 but, curiously, only in one instance, specifically when describing site 34C (Shiner 1968a), did Shiner consider the presence of this raw material as a sign of admixture. For sites 608, 619 and 621 Shiner excluded the possibility of later contamination. Egyptian flint presumably arrived in the Second Cataract region from the Western Desert in the Early Holocene (Usai 2008b). In two other Qadan sites - 605 and 621 - the evidence of admixture is shown by the presence of pottery (Usai 2008a and Table I.a, in this text). The potsherds found at site 621 are 44 and their descritpion is vaguely reminiscent of the pottery of the Mesolithic period or Khartoum Variant. 
Qadan sites, which were all surface concentrations, have been tentatively associated with the Sahaba Formation beginning more or less at I6,500 BP (Table I; De Heinzelin 1968) sometimes using circular arguments.

The Qadan has been defined as characterised by round or oval scrapers made on primary cortex flakes, Qadan points, burins and lunates, made mainly from blanks produced from single-platform cores, or opposed-platform ones whose striking platform could have been faceted or, secondarily, flat. It is defined as a flake industry but a blade component (Table 2.a and 2.b), sometimes relevant, is present and was used for the production of backed tools.

Apart from the Qadan sites in the Second Cataract region considered by Shiner (1968a), sites 8899 and 8905, located in the Ballana and Tuskha areas explored by Wendorf (Wendorf 1968a), are also more interesting for understanding the chronological position of the Qadan and establishing some criteria for defining the characteristics of this industry.

Indeed at site 8899, where also a stratified Sebilian occupation was found, most of the Qadan material was found on the surface, but a part was found in situ on the top of the Ballana sand (never more than 2 or $3 \mathrm{~cm}$ into the sand) and under the silt of the Sahaba formation (Wendorf I968a: 808, 8I4; Usai 2008a). The assemblage of site 8899 includes 163 artefacts $^{5}$ (34 primary flakes, 38 flakes, 2 blades, 17 chips, 39 cores, 33 tools). Five of these, two cores, two tools and one flake, were found under a small patch of Sahaba silt that was still in situ over the Ballana sand. ${ }^{6}$ Single-platform cores, with a faceted or un-faceted platform prevail. Opposed-platform cores, second in importance, may show faceted platform combined with an unfaceted one or with a cortex one.

Elaborated platforms still had their importance in Qadan core preparation technology. Many burins, backed flakes and blades, lunates, points are included within the tool sample but not a single scraper.

The collection at site 8899 is without doubt a very small one, although not much smaller than other assemblages illustrated by Shiner (1968a; Table 2.a), but the Qadan characteristics recognised in the few illustrated specimens (Wendorf 1968a: 8I2, Fig. I4)

5 Not much bigger are those assemblages that were found in the sites of the Second Cataract region (Shiner 1968a).

6 The hypothesis that the lithic industry may be associated with the interval between the Ballana sand and the Sahaba silt aggradation is further supported by Wendorf's (1968a: 809) following statements: "A remnant of the Sahaba silts was still present under a covering of young pediments near the base of the cliff. Silts also covered the northern edge of the dune [see Wendorf 1968a: Fig. I2] and part of the site to a depth of slightly more than a metre. Thin patches of undisturbed silt around $25 \mathrm{~cm}$ thick, remnants missed by the quarrying activities, occurred here and there over the dune and gave further proof that one time it had completely covered the Ballana sands" and (I968a: 8II) "The succeeding Qadan occupation [site 8899] may have occurred only slightly later, but prior to the time when the surface of the dune was covered by the aggrading Sahaba silts". 
Table I. Summary of contexts of Qadan sites in the Second Cataract region. After: Shiner I968a.

\begin{tabular}{|c|c|c|c|c|c|}
\hline Phase & Site & Nature of site and position & $\begin{array}{l}\text { Height } \\
\text { a.s.l. }\end{array}$ & $\begin{array}{l}\text { Height } \\
\text { a.f.p. }\end{array}$ & Formation \\
\hline \multirow[t]{4}{*}{$\begin{array}{l}\text { Early } \\
\text { Qadan }\end{array}$} & $81 \mathrm{~A}$ & $\begin{array}{l}\text { Surface site, incorporated into } \\
\text { a beach complex }\end{array}$ & & $20 \mathrm{~m}$ & $\begin{array}{l}\text { Sahaba } \\
\text { sands? }\end{array}$ \\
\hline & $34 \mathrm{C}$ & $\begin{array}{l}\text { Incorporated into a channel fill } \\
\text { of pea gravel }\end{array}$ & $?$ & ? & Sahaba? ${ }^{1,2}$ \\
\hline & 1046 & Surface site, on silt deposit & ? & $?$ & Sahaba? ${ }^{3}$ \\
\hline & 609 & Surface site, on silt deposit & $?$ & $?$ & Sahaba silt? \\
\hline \multirow{5}{*}{$\begin{array}{l}\text { Middle } \\
\text { Qadan }\end{array}$} & 2012 & Surface site, on sandy-silt deposit & $?$ & $?$ & Sahaba silt? \\
\hline & 1023 & Surface site, on silt deposit & $?$ & $?$ & $?$ \\
\hline & ANE-1 & $\begin{array}{l}\text { Surface site, on sandstone bedrock } \\
\text { or surface sand }\end{array}$ & $105 \mathrm{~m}(?)$ & & $?$ \\
\hline & S-320 & Surface site, on fluvial sand & $135-140 \mathrm{~m}$ & & $?$ \\
\hline & 608 & Surface site, on eroded silts (?) & $155 \mathrm{~m}$ & & Dibeira-Jer \\
\hline \multirow{3}{*}{$\begin{array}{l}\text { Late } \\
\text { Qadan }\end{array}$} & 619 & Surface site, on sand (?) & $145 \mathrm{~m}$ & & $?$ \\
\hline & 620 & Surface site, on sand & $145 \mathrm{~m}$ & & $?$ \\
\hline & 621 & $\begin{array}{l}\text { Surface site, on mixed widnblown } \\
\text { silt and sand }\end{array}$ & $144-146 m$ & & $?$ \\
\hline \multirow{4}{*}{$\begin{array}{l}\text { Final } \\
\text { Qadan }\end{array}$} & 1041 & Surface site, on windblown sand & & 12 & Sahaba \\
\hline & $605^{4}$ & Surface site, on loose sand & & 8 & post Sahaba \\
\hline & 2000 & Surface site & & $?$ & $?$ \\
\hline & 2003 & $\begin{array}{l}\text { Surface site, on hill of pre-Cambrian } \\
\text { rocks }\end{array}$ & & $20 / 30$ & $?$ \\
\hline \multirow[t]{7}{*}{ Abkan } & 2002 & Surface site, on silt & $145 \mathrm{~m}$ & & ? \\
\hline & 1029 & $\begin{array}{l}\text { Surface site, on rubble from } \\
\text { pre-Cambrian outcrop }\end{array}$ & $?$ & $?$ & Sahaba? \\
\hline & 604 & Surface site, on loose sand & ? & ? & $?$ \\
\hline & 629 & Surface site & & $3 / 4$ & $?$ \\
\hline & 2007 & Surface site, on pre-Cambrian rocks & & $9 \mathrm{~m}$ & $?$ \\
\hline & $94^{5}$ & Surface site, on silt & & $13 \mathrm{~m}$ & $?$ \\
\hline & 1001 & Surface site, on pre-Cambrian rock & & $?$ & $?$ \\
\hline
\end{tabular}

Height a.p.f. - denotes height of the site above the current level of the floodplain.

1 channel that contains pea-gravel and was created by high Nile floods, the association with Sahaba is made on comparison to materials from site $81 \mathrm{~A}$;

2 a silt deposition later than pea-gravel incorporating Qadan material was dated I2,550 460 bp (WSU-202);

3 silt type comparable to that of site $34 \mathrm{C}$ and 1028 ;

4 date on charcoal $6430 \pm 200$ bp (WSU-190);

5 a hearth $60 \mathrm{~cm}$ below the surface scattered with Abkan artefacts was dated $7300 \pm 250 \mathrm{bp}$ (Lab./no. ND; Shiner 1968a: 622). 
Table 2.a. Summary of Qadan sites assemblage composition. Descriptions are not homogenous and complete in Shiner's work (Shiner 1968a) compared to Wendorf's one (see Table 2.b; Wendorf i968a; 1968b).

\begin{tabular}{|c|c|c|c|c|c|c|c|c|}
\hline Phase & Site & Flakes & Blades & Cores & Tools & Debris & Total & Blade Tool Index \\
\hline \multirow{4}{*}{$\begin{array}{l}\text { Early } \\
\text { Qadan }\end{array}$} & $81 \mathrm{~A}$ & $!$ & $!$ & $?$ & 101 & $!$ & 101 & 11.3 \\
\hline & $34 \mathrm{C}$ & $!$ & $!$ & ? & 246 & $!$ & 246 & 18 \\
\hline & 1046 & $!$ & $!$ & $?$ & 63 & $!$ & 63 & 33.3 \\
\hline & 609 & $!$ & $!$ & $?$ & 104 & $!$ & 104 & 22 \\
\hline \multirow{5}{*}{$\begin{array}{l}\text { Middle } \\
\text { Qadan }\end{array}$} & 2012 & $!$ & $!$ & 168 & 101 & $!$ & 269 & 15.5 \\
\hline & 1023 & $!$ & $!$ & $?$ & 144 & $!$ & 144 & 32 \\
\hline & ANE-1 & $!$ & $!$ & $?$ & 873 & $!$ & 873 & 24.9 \\
\hline & S-320 & $!$ & $!$ & 47 & 283 & $!$ & 330 & $?$ \\
\hline & 608 & $!$ & $!$ & 98 & 145 & $!$ & 243 & 25.4 \\
\hline \multirow{3}{*}{$\begin{array}{l}\text { Late } \\
\text { Qadan }\end{array}$} & 619 & $!$ & $!$ & $?$ & 387 & $!$ & 387 & 67.7 \\
\hline & 620 & $!$ & $!$ & $?$ & 173 & $!$ & 173 & 70 \\
\hline & $621^{1}$ & $!$ & $!$ & $>1000$ & 1092 & $!$ & $>2092$ & 85 \\
\hline \multirow{4}{*}{$\begin{array}{l}\text { Final } \\
\text { Qadan }\end{array}$} & 1041 & \multicolumn{2}{|c|}{$>5000$} & $?$ & 380 & $!$ & $>5380$ & 32.4 \\
\hline & $605^{2}$ & $!$ & $!$ & $?$ & 320 & $!$ & 320 & 22.4 \\
\hline & 2000 & $!$ & $!$ & $?$ & 144 & $!$ & 144 & 11.1 \\
\hline & 2003 & $!$ & $!$ & 82 & 180 & $!$ & 262 & 7.2 \\
\hline \multirow[t]{7}{*}{ Abkan } & 2002 & $!$ & $!$ & 85 & 130 & $!$ & 215 & 15.3 \\
\hline & 1029 & $!$ & $!$ & 67 & 195 & $!$ & 262 & 4.4 \\
\hline & 604 & $!$ & $!$ & $?$ & 192 & $!$ & 192 & 2.0 \\
\hline & 629 & $!$ & $!$ & $?$ & 123 & $!$ & 123 & $?$ \\
\hline & 2007 & $!$ & $!$ & $?$ & 110 & $!$ & 110 & 2.7 \\
\hline & 94 & $!$ & $!$ & $?$ & 145 & $!$ & 145 & 0.9 \\
\hline & 1001 & $!$ & $!$ & $?$ & 97 & $!$ & 97 & 4.0 \\
\hline
\end{tabular}

! Data not reported;

? Data expressed only in percentage, absolute value unrecognisable;

1 site that produced 44 pottery sherds;

2 site that produced pottery sherds, ostrich eggshell and grinding stones (the presence of grinding stones at this site is mentioned by Shiner when describing site 1041 [1968a:603]). 
Io6 $\mid$ Donatella Usai

Table 2.b. Summary of Qadan site 8905 assemblage composition.

After F. Wendorf (Wendorf 1968a; 1968b). See Table 2a.

\begin{tabular}{|l|l|r|r|r|r|r|r|c|}
\hline \multirow{2}{*}{ Phase } & Site 8905 & Flakes & Blades & Cores & Tools & Debris & Total & $\begin{array}{l}\text { Blade Tool } \\
\text { Index }\end{array}$ \\
\hline \multirow{2}{*}{ Group I } & Locality A & 500 & 6 & 235 & 157 & 97 & 995 & 3.9 \\
\cline { 2 - 9 } & Locality B & 712 & 9 & 217 & 198 & 164 & 1261 & 3.5 \\
\hline \multirow{2}{*}{ Group II } & Locality C & 1095 & 26 & 182 & 342 & 555 & 2200 & 13.9 \\
\cline { 2 - 10 } & Locality D Surf & 2273 & 41 & 489 & 717 & 593 & 4113 & 16.1 \\
\cline { 2 - 10 } & Locality E & 358 & 9 & 178 & 161 & 41 & 747 & 21.9 \\
\cline { 2 - 9 } & Locality G & 518 & 9 & 204 & 116 & 4 & 851 & 14.3 \\
\hline \multirow{2}{*}{ Group III } & Locality F & 588 & 6 & 118 & 252 & 97 & 1061 & 23.1 \\
\cline { 2 - 9 } & Locality D Exc & 978 & 13 & 109 & 286 & 807 & 2913 & 26.5 \\
\hline
\end{tabular}

and the technological aspects are clear and are confirmed by the larger collections at different localities at Tushka site 8905 (Wendorf 1968a). Furthermore Wendorf (1968a: 8I4) clearly states that "the value of this assemblage lies with the information which it imparts concerning the relationship between the Sahaba silts and an industry of the general technological and typological level represented by this assemblage".

There is at least another locus in the Second Cataract area that has produced material very similar to the Qadan complex which it seems necessary to consider in more depth. This is site 412, where a $3 \mathrm{~m}$-thick deposit of Sahaba silt was covering the sands on which the artefacts were lying or slightly embedded. The lithic industry of this site was attributed to the Gemaian (a very poorly defined complex preceding the Qadan with which it shares many characteristics). The number of Qadan points, a pointed flake obtained from a "Levallois-like" core (see Shiner 1968a: Fig. 2rh-m), accompanying the whole tool sample is remarkable (Shiner 1968a; Marks 1970) and apart from this, "the assemblage at 412 has varying frequencies of all the tools represented at 278 [that is a Gemaian-Qadan site] and of all tools of the Qadan industry with the exception of the geometrics" (Shiner 1968a: 56I). Apparently, Shiner, by the use of the label "geometrics" intended lunates, and it is worth emphasising that this tool is not as common even in the assemblages of the so-called Early Qadan phase (see site 81A or even site 1046). Site 412 also produced a conspicuous amount of backed bladelets.

7 We wonder whether this is not another case of admixture, a confirmation of which may also be the presence of "proto-gouges" (Shiner 1968a: 56I, Fig. I7). 
Also at Tuskha, the Qadan evidence in the different parts of site 8905 (Table 2.b) was found resting on the eroded sands of the Ballana Formation (Albritton 1968: 856-864; Wendorf I968a: 935-940). ${ }^{8}$ The area was occupied by a freshwater lake before the deposition of Nile silts of the Sahaba aggradation and was an attraction for groups that left behind assemblages in different locations with definite Qadan affinities (Wendorf 1968a: 935-940).

As a result, it would seem therefore that there is a possibility for the Qadan to be placed in a more specific chronological period, at the end/on top of the Ballana Formation, as Wendorf's sites 8899 and 8905 suggest.

As for the characterization of the Qadan assemblages, cores and debitage were not systematically described in Shiner's reports (1968a; Table 2.a), which concentrated more on the descriptions of the tools. However it can be definitely stated that the Qadan lithic industry made ample use of single-platform cores, usually representing about $50 \%$ of a core sample, followed by opposed-platform cores, usually around $35 \%$. Cores reminiscent of the Levallois types, those with which Qadan points production can be associated, may be present and also some bipolar specimens. Multi-platform cores are absent. Qadan cores are small in size (a mean length of 31.44 mm: Shiner 1968a: 573; Fig. 3). Platforms are mainly faceted (and convex in shape) but may otherwise be flat, or, rarely, cortex; the platform angle is mostly acute, ranging between $65^{\circ}$ and $75^{\circ}$, in the case of flat or faceted platforms (Usai pers. obs.). The dorsal surface of the core is cortex, apart from platform-faceting scars (Fig. 3).

The Qadan industry is mainly oriented to flake production, but blades are present in various assemblages. According to Shiner, but also to Wendorf (1968a: 853), the occurrence of bladelets is not consistent with the Qadan. However some sites, 609-619-620621 (Fig. I), have a significant percentage of backed bladelets (Table 2.a). At site 621, for example, notwithstanding the presence of an intrusive later admixture, a certain amount of blades corresponding to a sample of typical Qadan cores with blade scars, had been produced (Usai 2008a). These blades form around 8\% of the debitage sample and backed pieces $42.9 \%$ of the whole tool sample. When blades are completely lacking, as in site $81 \mathrm{~A}$, it may be either because the site had a specific use or, most probably, because of its state of preservation. When looking at Qadan cores in illustrations, there are clearly some that were used for blade production. ${ }^{9}$

8 Another site of the Qadan complex that is resting on sand is 81A. These sands were considered pertaining to the Sahaba formation (De Heinzelin 1968: 47; Shiner 1968: 565) but we wonder whether it is possible that the sands from site 81A correspond to the Ballana sands and not to those at Sahaba. Another site resting on sand covering an area of eroded sandstone bedrock is ANE-1. It has an abundant sample of tools. Site S-320 also is on fluviatile sands.

9 For example Shiner 1968a: Fig. 31: r and s; Fig. 36: a and c. 


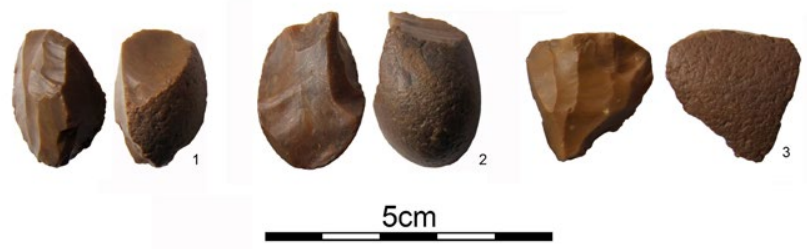

Fig. 3. A few typical Qadan cores from site 8899. I - opposed platform core; 2, 3 - single platform cores. Photo: D. Usai, courtesy British Museum.

Concerning Qadan tool production, if we exclude points and burins, scrapers and lunates, ${ }^{10}$ the other most common tool types in these assemblages, should be considered diagnostic only with some caution. These tools, in fact, are also found in the Arkinian, Shamarkian, Post-Shamarkian, Khartoum Variant and Abkan complexes. Since it has been determined that in Qadan sites of the Second Cataract region, there had been an admixture of material pertaining to these complexes (see also Usai 2008a), it would be difficult to distinguish among those that are really Qadan types and those that are not. Indeed scrapers produced in these later lithic industries are mainly made from cortex primary flakes, and the typology of lunates does not vary much throughout the millennia between the Arkinian and Abkan periods. However scrapers typical of the Qadan phase are decidedly smaller than those of later periods.

At this point, it becomes hard to maintain that the Qadan is a lithic industry lasting several thousand years (from around 15,000 to until 6000/5000 BP according to Shiner) ${ }^{11}$ divided into four different phases and ending in the Abkan, that is plain Neolithic. This suggests a revision of the cultural sequence of the very Late Pleistocene to / Early to Middle Holocene Nubian lithic industries. This revision includes the reanalysis of the technological aspects of the Ballanan, a lithic industry also located on top of eroded Ballana sands (see site 8956, Wendorf 1968a), which includes core types similar to those of the Qadan (single and opposed platform cores) and new ones, like multi-platform (absent in the Qadan) and bipolar ones (rare but present in the Qadan), with similar size and platform preparation (Fig. 4; for a detailed analysis

10 Or backed flakes approaching lunates in shape.

11 Dates of the Qadan-Abkan sequence falling in the Holocene period were, as a matter of fact, excluded by Wendorf when pointing out the poor reliability of Shiner's stages. However, rather contradictorily, Wendorf (1968b: 990) in the paragraph "Discussion of artifacts from Jebel Sahaba" states that "...the Qadan industry [...] is estimated to have begun around 13,000 B. C. and to have continued until the appearance of pottery around 5,000 B. C." Later on, in a paper co-authored by Schild and Wendorf (2010) the Qadan is delimited to a period between 17,500 and 16,500 cal BP. 

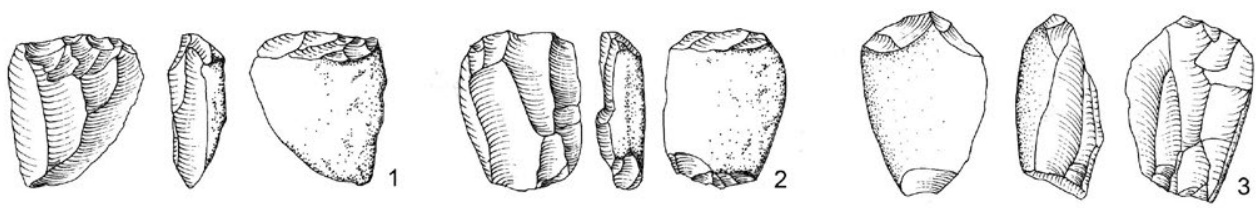

$5 \mathrm{~cm}$

Fig. 4. An example of a Ballanan core. I - single platform core; 2, 3-opposed platform cores. After Wendorf 1968a: Fig. 3I.

see Usai 2008a). ${ }^{12}$ Looking further at the technological aspects, we can affirm that the evolutionary stage that we see in this industry foretells the characteristics that will develop widely in the Arkinian (Usai 2008a): very high percentages of single-platformcores, a decrease in importance of opposed-platform ones, coupled by a growth in multi-platform cores and an ample use of the bipolar-on-anvil technique (see also Usai 2008a). This revision led finally to demonstrating the possibility of a local evolution from the Qadan to the Abkan but through the Ballanan, Arkinian, Shamarkian and Post-Shamarkian complexes, based on the assumption that we can recognise, along a time continuum, an oversimplification of core treatment with the appearance of new exploitation techniques, an increase in size and some peculiar stylistic characteristics that are passed from one cultural sphere to the other (Usai 2008a: Fig. 4.I7).

\section{THE SMALL JEBEL SAHABA CEMETERY AND THE LITHIC ASSEMBLAGE}

The Jebel Sahaba cemetery was discovered in 1962 three kilometres north of Wadi Halfa and not far from an inselberg known as Jebel Sahaba (Wendorf 1968b). It is renowned for representing the first known case of warfare (Wendorf 1968b; Anderson 1968), because four out of the 58 individuals buried at the cemetery had fragments of flint tools embedded in the bones (Wendorf 1968b: 990). ${ }^{13}$ Most of the work at the site was done by F. Wendorf in 1965 but A. Marks carried out some additional excavation in 1966, discovering six more skeletons (Wendorf 1968b). The cemetery

12 Wendorf (1968a: 853) states that the Qadan shares more features with the Ballanan than any other complex.

13 M. Judd (2006) in her re-analysis of the Jebel Sahaba skeletal material discovered two new embedded lithic chips in the remains from one of the graves. 
was dated on the basis of the associated artefacts and uncertain geological evidence to I2,000/IO,000 BC (Wendorf I968b: 954), ${ }^{14}$ corresponding more or less to the Qadan phase. A date on collagen was obtained from skeleton 43 (Pta-116 13,740 \pm 600 uncal. BP; Wendorf and Schild 1989) but regarded as suspicious because the sample was processed in a period when AMS was not available and extraction procedures were not properly implemented (Antoine et al., 20I3). New dates on apatite were more recently obtained for four skeletons that seem to provide a different chronological framework (Table 3; Zazzo 20I4), with dates falling more in the Early Holocene than Late Pleistocene.

Near the cemetery it was postulated that there might have been a Qadan site but the occupation "may be concealed beneath the slope wash which hid the graves" (Wendorf 1968b: 955). Most graves were covered by sandstone slabs but some postdepositional re-arrangement may have taken place, ${ }^{15}$ part of them were exposed almost on the surface but the majority were found at depths between $35 / 40$ and $60 / 70 \mathrm{~cm}$ (Wendorf 1968b: 957). Skeletons were apparently buried in pits that are said to have been oval in outline even if only in one case (Burial 7) was the pit-shape reported. The graves were very homogeneous in their orientation, east-west with head to the east and facing south, with the bodies in a flexed position and on the left side.

Wendorf (I968) states that IIO artefacts ${ }^{16}$ were in direct association with the burials and their position indicated that they had penetrated the bodies as point or barbs. These artefacts were documented in 26 ( 24 certain, plus 2 doubtful) out of the 58 burials recovered at the site. The total number of artefacts found in the area of the cemetery is 189,86 were tools or retouched pieces and 97 un-retouched chips and flakes. ${ }^{17}$ Of these last ones 25 chips, 22 flakes and two primary flakes are said to have been associated with the burials while the remaining 48 artefacts ( 30 flakes, 13 primary flakes and 5 chips, mostly of fossil wood; Fig. 5 and 6) were recovered in the fill of the excavated area (Wendorf I968b: 989). However, Wendorf supposes that they may have an origin similar to a large number of worn and eolized sandstone flakes that were, instead, considered as derived from the Middle Palaeolithic site located on top of an adjoining inselberg. Also in the fill of the excavated area were six cores: one possible Levallois (?), one single platform, one multiplatform in doubtful association

14 Reported from Wendorf 1968b: 954; the calibration is that used at that time, subtracting 1950 from the laboratory date.

15 In one case, burial 47, the skeleton was "on the sandstone slab".

16 There is a small discrepancy in that Wendorf (I968b) on page 959 mentions a direct association of IIO artefacts while on page 982 he mentions II 6 flaked stone artefacts found in direct association with 24 of the burials.

17 The lithic assemblage recovered by Wendorf at Jebel Sahaba is held in the British Museum, which is here thanked for permission to study it and reproduce photos made by the author. 
The Qadan, the Jebel Sahaba Cemetery and the Lithic Collection $\mid$ III

Table 3. Recent dates from Jebel Sahaba cemetery. After: Zazzo 2014.

\begin{tabular}{|c|l|l|c|}
\hline Grave number & Material & AMS Lab & Date uncal BP \\
\hline 15 & Enamel apatite & UBA-20124 & $7251 \pm 31$ \\
\hline 15 & Dentine apatite & UBA-20132 & $11660 \pm 52$ \\
\hline 15 & Bone apatite & UBA-20125 & $11049 \pm 43$ \\
\hline 22 & Enamel apatite & UBA-20126 & $8512 \pm 40$ \\
\hline 22 & Bone apatite & UBA-20127 & $11133 \pm 50$ \\
\hline 42 & Enamel apatite & UBA-20128 & $9043 \pm 45$ \\
\hline 42 & Bone apatite & UBA-20129 & $11093 \pm 49$ \\
\hline 103 & Enamel apatite & UBA-20130 & $9687 \pm 55$ \\
\hline 103 & Bone apatite & UBA-20131 & $10032 \pm 46$ \\
\hline
\end{tabular}

with burial 50-51, an opposed sides and three others. According to Wendorf's report, they were "all found in the excavation fill" (Wendorf 1968b: 990).

While most artefacts are microlithic, a significant number of them cannot be included in this category. Wendorf suggests this material resembles assemblages of the Qadan, even if he notes the scarcity of lunates that are characteristic of this lithic industry. Only one, but doubtful, example was found and not in direct association with any of the burials. He also underlies the similarity between the small Jebel Sahaba sample and that of a "Middle Qadan" site ANE-1 (Shiner 1968a). Wendorf (1968b: 990-99I) establishes a date for the cemetery based on the general characteristics of the assemblage and especially on this single doubtful lunate and on the supposed contemporaneity with the burials.

\section{COMMENTS}

While there is strong evidence that the cemetery was the result of a single violent event (the number of individual with bone-embedded lithics, the number of simultaneous burials, the quasi perfect iso-orientation of nearly all ${ }^{18}$ of them) there are reasons to think that it is not as certain that all the lithic artefacts found in the burials were in "association" with them. Contrary to Wendorf's claim (I968b: 99I), it does not sound so unreasonable to think that part of the artefacts found near the skeletons, or even

18 Only two burials observe a different orientation. 
II2 Donatella Usai
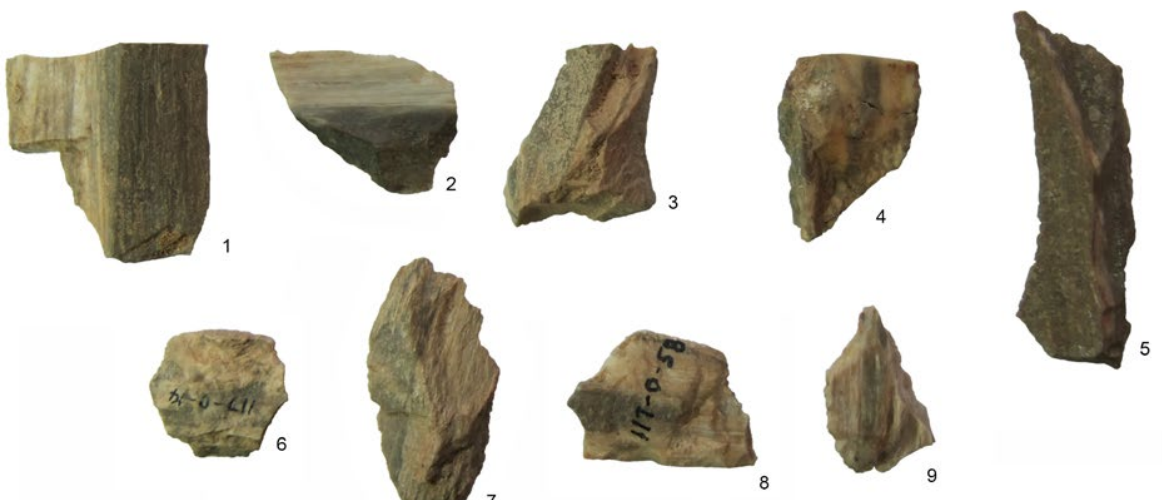

\section{$5 \mathrm{~cm}$}

Fig. 5. Fifteen out of the twenty-one unpublished fossil wood flakes from site 117. I, 4 and 8 - are broken. Photo: D. Usai, courtesy British Museum.
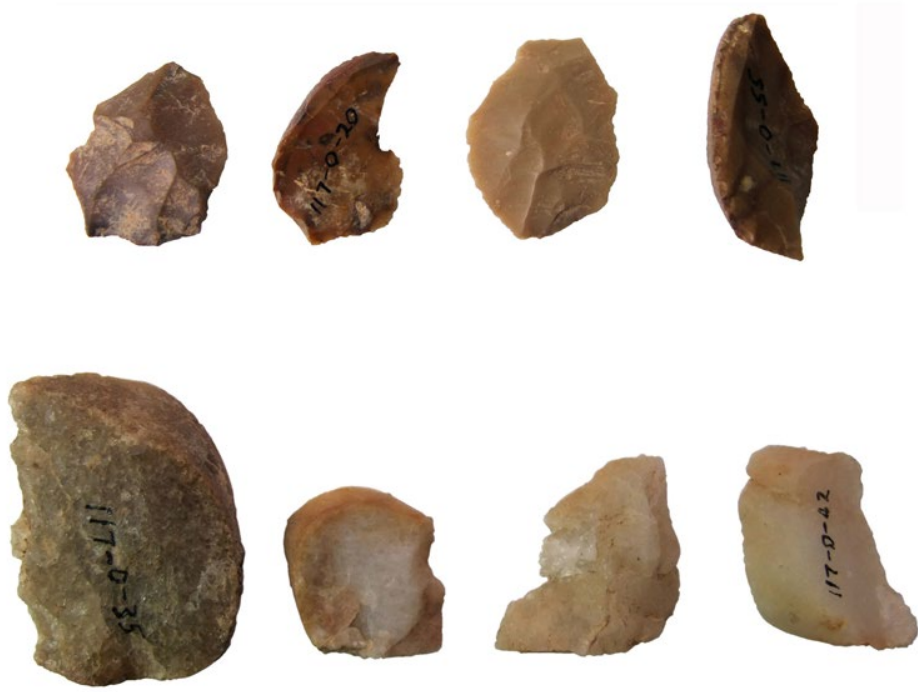

\section{$5 \mathrm{~cm}$}

Fig. 6. Unpublished chert and quartzite flakes from site 117, exact location was not reported in the bag containing them.

Photo: D. Usai, courtesy British Museum. 
inside their skulls, happened to reach that position due to post-depositional factors (especially if no evidence of trauma are present on the bones). Of the four burials where fragmentary flints were found embedded in the bones (Burials 21, 23, 31 and 103) three had a large number of other artefacts around them (Burial 21, 19 artefacts; burial 31, 17 artefacts; and burial 44, 21 artefacts; Fig. 7) and it is almost incredible that all of them result from wounds inflicted on each of these individuals with arrows. They are not furthermore in particular position to consider that they were the results of an intentional deposition. In the case of Burial 44, twenty-one artefacts (Fig. 8; tools and also un-retouched pieces) were considered associated with the skeleton but surprisingly not even one was found embedded in the bones. ${ }^{19}$ Three of the artefacts that were found in front of the mandible, inside it and behind it in burial 44 (Fig. 8), have been described as aligned and supposed to be possible "barbs and point on shaft" (Wendorf 1968b: 978). If these tools really had been the remains of a weapon consisting of a shaft with a flint point and barbs, the wound that such a weapon could have produced on the facial bones (especially the maxilla and the mandible) of this individual would have been unmistakable. There is however no mention of this in Wendorf's notes, nor in Anderson's study. There is no photo of this grave but according to the description and the plan (Wendorf 1968b: Fig. 3) the grave was entire with the skull present. ${ }^{20}$

On this same line of reasoning, artefacts found inside skulls of burials 14 and 21 (Fig. 7) may have found their way there transported by any small animal whose traces of disturbances may have disappeared completely, especially as the deposit in which the pit-graves had been excavated is made mostly of sand. ${ }^{21}$

This suggests that there is a possibility that part of the lithic artefacts that were found in the graves of Jebel Sahaba resulted from an admixture created by the digging of the pits for the internment of each individual or group of individuals at points where more ancient levels of occupation were intercepted. After all, this possibility is not denied by Wendorf himself and would explain the cores that were not in direct association with any of the burials, and flakes or chips that are described as "in fill adjacent to skeleton, position unknown" (for example as in burial 44), and the 48 artefacts that were recovered in the fill of the excavated area, most of them made of petrified wood, not similar to the Qadan typologically (Fig.5 and 6). This would also explain why, among artefacts that were considered associated with the graves, are also present types that cannot so easily be linked to weapons (scrapers, denticulates and some truncations). This means that the lithic assemblage found at Jebel Sahaba may rely to an occupation

19 According to the list of Wendorf 1968a: 990, even if in description of the burial on page 978, one is described as "(a) backed flake, imbedded in right fourth rib, near vertebra (Fig. 3r:l)".

20 The skull and mandible were present and are currently in the collection at the British Museum; we wish to thank to Dr D. Antoine for confirmation of this.

21 At the al-Khiday cemetery a Meroitic faience bead was found under the mandible of a pre-Mesolithic skeleton, presumably transported by a tiny rodent tunnelling in that place (pers. observ.). 



Fig. 7. Burial 14, 20 and 21 and the distribution of artefacts located in them, none embedded in the skeletons. Re-elaborated from Wendorf I968a.

pre-dating the use of the area as a cemetery. The dating of this lithic assemblage can therefore be approached only from its typology. Notwithstanding the absence of lunates (as mentioned above, they cannot be considered as reliable indicators of the Qadan), a lot of the other artefacts described in this assemblage can with some certainty be associated with the Qadan lithic industry. Less certain however is the association with this same phase of part of the debitage (especially the fossil wood specimens, and some of the cores, which are not in the same condition of wear, like the wind-blasted and worn sandstone flakes that are assigned to the Middle Palaeolithic).

Several dates for the Qadan lithic industry, which according to this revision (see also Usai 2008a) does not last as long as Shiner (1968a) had suggested, ${ }^{22}$ were obtained from the Tuska area (Wendorf i968a: 940) on charcoal - I4,500 \pm 490 uncal BP (WSU$315)^{23}$ - and on carbonates - $10,530 \pm 126$ uncal BP (WSU-415b), 9730 $\pm \mathrm{I} 20$ uncal BP (WSU-444) ${ }^{24}$ and II,400 \pm 70 uncal BP (WSU-417 combined with WSU-442). ${ }^{25}$ Another date on charcoal - 15,100 \pm 800 uncal BP (GXO-413) - from Qadan site 6G33 located in an area opposite to Wadi Halfa (Irwin et al., 1968) is similar to that of Tuska.

22 As a reminder, Wendorf (1968b: 990), contradicting himself and, again, following Shiner (1968a) states that "the Qadan industry is estimated to have begun around $\mathrm{I3}, \mathrm{OOO} \mathrm{BC}$ and to have continued until the appearance of pottery around $5000 \mathrm{BC}$ ". Locality $\mathrm{C}$ at the Tushka site.

24 Locality $\mathrm{F}$ at the Tushka site.

25 Locality A and $\mathrm{C}$ at the Tushka site. 

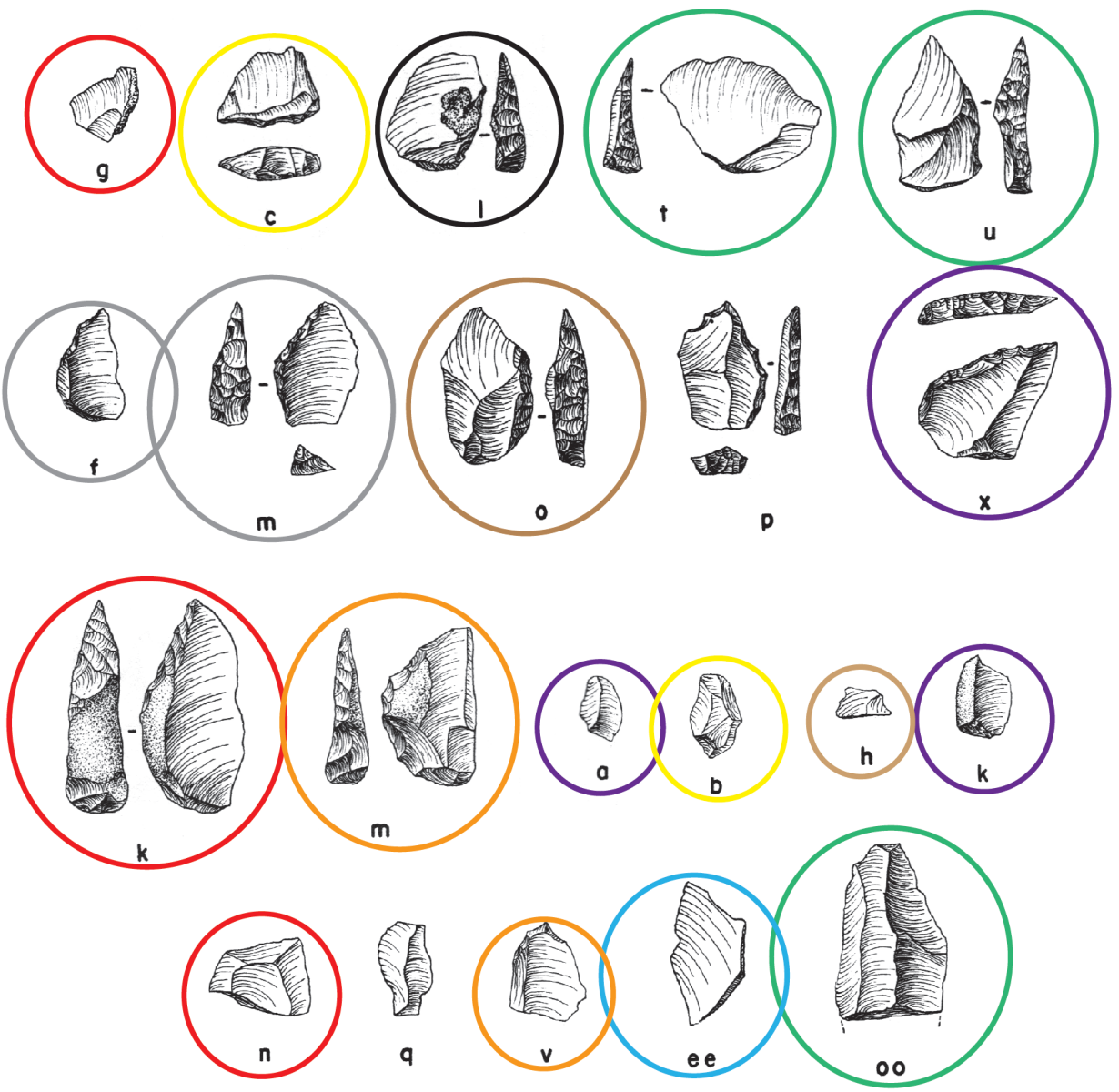

Fig. 8. Artefacts recovered in burial 44 (scale 4:5; reassembled from Wendorf i968a: Figs 3I-34): pieces in red circles were considered "barbs and point on shaft in mouth"; those in green circles were found near the lumbar vertebra; blue ones, at the distal end of the right femur; orange, inside pelvic cavity; pink, inside rib cage; brown, in spinal column; grey, against ventral face of scapula; yellow, against fifth rib, near vertebra; black one, embedded

in the fourth right rib, near the vertebrae; light brown, proximal end of right humerus; not encircled, pieces in fill adjacent to skeleton but exact position unknown (Wendorf i968a: 978). 
The dates on carbonates may be regarded as unreliable as Wendorf states (1968a; for the problem see also Dal Sasso et al., 2016; 2018). The Qadan assemblage of site $34 \mathrm{C}$, included in a pea-gravel deposit, at higher elevation than usual, is dated before $12,550 \pm 460 \mathrm{BP}$ (WSU-202) on the base of a recessional feature regarded as later than the channel itself. Therefore the most probable chronological position of the Qadan industry seems to be $-15,000 \mathrm{BP}$ (or 17,000 cal BP; Schild and Wendorf 2010).

A date on a hearth from site $8896-14,000 \pm 280$ uncal BP (WSU-329) - puts the Ballanan, ${ }^{26}$ here considered as contiguous with the Qadan (if not simply a facies of the latter; Usai 2008a) in a slightly later period.

Provided that the dates for the Qadan-Ballanan phases are reliable, if the association between the Jebel Sahaba burial and the lithic industry found inside the burials can be questioned, then the cemetery post-dates $\sim \mathrm{I} 5, \mathrm{OOO} / \mathrm{I} 4, \mathrm{OOO} \mathrm{BP}$. If the recent dates obtained on the burials (Table 3; Zazzo 20I4) can be accepted, the cemetery would correspond more to the period when the Arkinian lithic industry developed in the region (Schild et al., 1968). ${ }^{27}$ However, the recent dates of Jebel Sahaba cemetery should be considered with great caution as it seems that the problem of the dissolution and re-precipitation of calcite that may significantly contaminate the carbon isotope proportions of the bioapatite may have been underestimated, as documented for other cases in Central Sudan (Dal Sasso et al., 20I6; 20I8). It is tempting to correlate the carbonate dates obtained for the cemented material from three localities in the Tushka area (WSU-415b, WSU444 and WSU-417, reported above), ranging between 9730 and II,400 BP, with those dates produced by dating enamel, dentine and bone apatite of four of the Jebel Sahaba burials. It is worth noting that Wendorf (1968b: 959) reports that:

\footnotetext{
"After the burials were filled, a calcified crust developed over the grave pits, and then this crust was covered by slope wash from the adjacent inselberg. ... The crust is of some chronological significance for it does not occur over Neolithic or later Historic material in Nubia and, consequently, indicates a pre-Neolithic date for the burials".
}

Therefore, if we consider the possibility of a correlation between the cemented dated material from Tushka and the formation of this calcified crust, then the skeletal remains of the cemetery of Jebel Sahaba may also have suffered from secondary calcite precipitation, a phenomenon generally occurring during periods of aridity (Dal Sasso et al., 20I8). This finally means that, as also suggested by Zazzo (20I4), the new Jebel Sahaba dates should be considered as minimum dates.

26 Similar to it, and most probably the same industry, is what Irwin et al., (1968) has called the Dabarosa complex.

27 However this does not necessarily mean that the population should be assigned to this specific cultural phase as similarly assessed by Wendorf for the Qadan (1968: 990): "the assignment of the artifacts found in the skeletons to the Qadan industry does not necessarily imply that the skeletons were representative of a Qadan population”. 


\section{CONCLUSIONS}

The recovery of the Nubian cultural and geological sequence of the region of the Second Cataract area is the result of the immense effort made by researchers from all over the world during the Nubian Campaign. Many aspects of the sequence have been revisited thanks to the results of research in neighbouring areas and also thanks to the improvement of dating techniques (Schild and Wendorf 20IO). Among the lithic complexes of the end of the Late Pleistocene, the Qadan is the one for which there have been more difficulties in establishing a precise chronology. The original fourstage division of the complex proposed by Shiner (1968a) was discussed, already in its time, by Wendorf, but the same was not done for the hypothesis of the Qadan-Abkan relationship. The arguments presented in this paper, although they would require confirmation by new radiometric data, seem plausible and attempt to resolve the question of the Qadan and the Abkan, regarding them as two distinct typologically and chronologically well separated complexes. The eight/nine thousand years considered originally as the chronological time frame within which the two complexes developed, in fact constitutes the time that elapsed between them. Other complexes, Ballanan, Arkinian, Shamarkian (= Khartoum Variant) and Post-Shamarkian (= Abkan; Wendorf 1968c), better fit into this temporal and evolutionary frame.

Like the sites at Tushka (Wendorf 1968a), the Jebel Sahaba cemetery has been dated to the Qadan period, therefore this revision has required also a re-analysis of this important context. The recent dates obtained from the enamel and bone apatite of four of the 58 individuals recovered at the Jebel Sahaba cemetery fall in the temporal gap between the Qadan and the Abkan. A review of the overall Jebel Sahaba context and the associated lithic assemblage suggests that even if it seems established that part of the lithic artefacts can be attributed to the Qadan, there are reasons why the association of these flints with the individuals in the cemetery should be re-examined. Therefore if the cemetery cannot be dated to the Qadan, one wonders which cultural phase it can be associated with. The new dates on the Jebel Sahaba indicate a wide range, between $\sim \mathrm{II}, 500$ and $-7000 \mathrm{BP}$, the oldest of which would partially fall within the period of the Arkin formation, with the Nile aggrading probably under better climatic circumstances. Although the evidence is rather weak, it is worth remembering that Judd (2006), in her later study of the Sahaba population remarks, using Schild and Wendorf's (2010) words, that

"in spite of evident violence and aggression, [the community] was not undernourished or impoverished and was much better off than some of the younger Nilotic societies such as the later Badarian and Dynastic ones (Judd 2006: I60)".

As the new dates on Jebel Sahaba cemetery may be "minimum dates" (see also Zazzo 20I4), the suggestion that the population corresponds to the time of the Arkin formation 
(= Arkinian lithic complex) may be considered with cautious. Perhaps, however, it can be considered as a useful indication that we should seek to place it in the temporal space between the Qadan and Abkan, at a moment when climate and environment may have been best suited for a hunter-gatherer population to grow "well nourished and not impoverished".

\section{ACKNOWLEDGMENTS}

I would like to thank the editors of the volume for inviting me to contribute at it. I have always been fascinated by the gentle ways of Professor Michał Kobusiewicz, whom I had the pleasure to meet many years ago when I was a young student. During the working experience I had with him, and together with our colleague Jacek Kabacinski, I learned many things and, above all, to be systematic in the study and analysis of lithic assemblages. I am happy to be able to dedicate this little piece of criticism to him, made possible only by the accuracy with which Michał and the late Prof. F. Wendorf always published their works.

Many thanks are also due to the two reviewers whose comments helped me to improve the work.

\section{REFERENCES}

Albritton, C. C. Jr. 1968. Geology of the Tushka site: 8905. In F. Wendorf (ed.), The Prehistory of Nubia Vol. II, 856-846. Dallas, Southern Methodist University Press.

Anderson, J. E. 1968. Late Paleolithic skeletal remains from Nubia. In F. Wendorf (ed.), The Prehistory of Nubia Vol. II, 996-I040. Dallas, Southern Methodist University Press.

Antoine, D., Zazzo, A. and Friedmann, R. 2013. Revisiting Jebel Sahaba: new apatite radiocarbon dates for one of the Nile valley's earliest cemetery. American Journal of Physical Anthropology, Supplement 56: 68.

Binford, L. 1979. Organization and formation processes: looking at curated technologies. Journal of Anthropological Research 35(3): 25I-273.

Binford, L. 1980. Willow smoke and dog tails: hunter-gatherer settlement system and archaeological site formation. American Antiquity 45: I-I7.

Dal Sasso, G., Lebon, M., Angelini, I., Maritan, L., Usai, D. and Artioli, G. 20I6. Bone diagenesis variability among multiple burial phases at Al Khiday (Sudan) investigated by ATR-FTIR spectroscopy. Palaeogeography, Palaeoclimatology, Palaeoecology 463: 168-179.

Dal Sasso, G., Zerboni, A., Maritan, L., Angelini, I., Compostella, C., Usai, D. and Artioli, G. 20r8. Radiocarbon dating reveals the timing of formation and development of pedogenic calcium carbonate concretions in Central Sudan during the Holocene. Geochimica et Cosmochimica Acta 238: 16-35.

D'Ercole, G. 2017. Ceramic manufacturing techniques and cultural traditions in Nubia from the 8th to the 3 rd millennium BC. Oxford Archeopress Publishing Ltd. Cambridge Monographs in African Archaeology. 
De Heinzelin, J. 1968. Geological history of the Nile valley in Nubia. In F. Wendorf (ed.), Prehistory of Nubia Vol. I, 19-55. Dallas, Southern Methodist University Press.

Irwin, H. T., Wheat, J. B. and Irwin, L. F. 1968. University of Colorado investigations of Palaeolithic and Epipaleolithic sites in the Sudan, Africa. Salt Lake City, University of Utah. Anthropological Papers 90.

Judd, M. 2006. Jebel Sahaba revisited. In K. Kroeper, M. Chłodnicki and M. Kobusiewicz (eds), Archaeology of Early Northeastern Africa, I53-166. Poznań, Poznan Archaeological Museum.

Lermolieff, I. I890. Kunstkritische Studien über Italienische Malerei. Die Galerien Borghese und Doria Panfili in Rom. Leipzig, F. A. Brockhaus.

Marks, A. E. 1970. Preceramic Sites. Stockholm, Scandinavian University Books. The Scandinavian Joint Expedition to Sudanese Nubia Publications 2.

Nordström, H. A. (ed.) 1972. Neolithic and A-Group sites. Stockholm, Scandinavian joint expedition to Sudanese Nubia 3, Scandinavian University Books.

Schild, R. and Wendorf, F. 20Io. Late Palaeolithic Hunter-Gatherers in the Nile Valley of Nubia and Upper Egypt. In E. E. A. Garcea (ed.), South-Eastern Mediterranean Peoples Between 130,000 and I0,000 Years ago, 89-I25. Oxford and Oakville, Oxbow Books.

Schild, R., Chmielewska, M. and Więckowska, H. 1968. The Arkinian and Shamarkian industries. In F. Wendorf (ed.), Prehistory of Nubia Vol. II, 65I-767. Dallas, Southern Methodist University Press.

Shiner, J. L. 1968a. The Cataract Tradition. In F. Wendorf (ed.), Prehistory of Nubia Vol. II, 535-629. Dallas Southern Methodist University Press.

Shiner, J. L. 1968b. The Khartoum Variant. In F. Wendorf (ed.), Prehistory of Nubia Vol. II, 768-798. Dallas, Southern Methodist University Press.

Usai, D. 2005. Early Holocene seasonal movements between the Desert and the Nile Valley. Details from the lithic industry of some Khartoum Variant and some Nabta/Kiseiba sites. Journal of African Archaeology 3(I): IO3-II5.

Usai, D. 2008a. Lunates and micro-lunates, cores and flakes: The lithic industry of R12. In S. Salvatori and D. Usai (eds), A Neolithic cemetery in the Northern Dongola Reach (Sudan): Excavation at Site R12, 33-52. London, The Sudan Archaeological Research Society Publications.

Usai, D. 2008b. Tracing the movements of the Western desert dwellers. Site 11-I-13 in Wadi Karagan, Sudanese Nubia, closely akin to El Ghorab or El Nabta. Journal of African Archaeology 6(2): 219-232.

Welsby, D. 1997. Early Pottery in the Middle Nile Valley. In I. Freestone and D. Gaimster (eds), Pottery in the making. World ceramic traditions, 26-3I. London.

Wendorf, F. 1968a. Late Palaeolithic sites in Egyptian Nubia. In F. Wendorf (ed.), The Prehistory of Nubia Vol. II, 79I-953. Dallas, Southern Methodist University Press.

Wendorf, F. 1968b. Site 117: a Nubian Final Palaeolithic graveyard near Jebel Sahaba. In F. Wendorf (ed.), The Prehistory of Nubia Vol. II, 954-995. Dallas, Southern Methodist University Press.

Wendorf, F. (ed.) 1968c. The Prehistory of Nubia Vol. I, II. Dallas, Southern Methodist University Press.

Wendorf, F. and Schild, R. 1989. Summary and Synthesis. In A. E. Close (ed.), The Prehistory of Wadi Kubbaniya. Late Paleolithic Archaeology Volume 3, 768-824. Dallas, Southern Methodist University.

Zazzo, A. 20I4. Bone and enamel carbonate diagenesis: a radiocarbon prospective. Palaeogeography, Palaeoclimatology, Palaeoecology 4I6: I68-178. 
